\title{
Interpretation and analysis of cross media content: the case of Televisió de Catalunya ${ }^{1}$
}

\author{
Rosa Franquet \\ Catedrática de Comunicació Audiovisual \\ Universitat Autònoma de Barcelona \\ Rosa.franquet@uab.cat
}

\author{
María Isabel Villa Montoya \\ Facultad de Comunicación Social \\ de la Universidad Pontificia Bolivariana
}

\begin{abstract}
Audiovisual content found on digital technologies a natural expansion path, which has been accelerated thanks to the convergence. Mass Media strategies have focused on developing multiplatform content in order to exploit the potential distribution on the market. This article is about the theories and concepts related to measurement and cross-content, in turn, analyses one of the most ambitious multiplatform productions in Television de Catalunya, "Guernica: war paint." The purpose is to understand the scale of the issue from an interdisciplinary perspective and put the issues inherent in the study and analysis of cross-media productions. The text brings together the contributions of authors from different perspectives that have examined the content through concepts such as remediation, intertextuality, and transtextuality. The results indicate that the passage of pieces of content across different platforms used by television and radio operators happen more and more natural thanks to the experience accumulated over the past decade. The audience access multimedia motivated proposals complementary to television flow, attracted by the expansion of the contents and the establishment of a strong and proactive relationship with the audiovisual product. The documentary review escapes from the linear narrative and presents personalized and interactive content. However, we can speak of a hybridization between the total contents because the use of common tools and the degree of integration of technologies and production practices is still in an initial state.
\end{abstract}

Keywords: cross-media production, content, interactive, intertextuality, television, multi-platform, convergence.

1. The results included in this report form part of the $\mathrm{PhD}$ thesis Cross-Media Production. The case of Televisió de Catalunya and the research project Cross Media Environment: organisational and productive transformations in radio and television groups (CSO2009-09367), financed by the Spanish Ministry for Science and Innovation as part of the National R+D+I Plan and developed by the Image, Sound and Synthesis Research Group and (GRISS) at the Universitat Autònoma de Barcelona (2009SGR1013). 


\section{Approach to the theories and concepts associated to cross-media content}

In the current process of convergence, television production is starting to be understood transversally in order for each medium to act beyond its own limits. For radio and television operators, such a task represents an unprecedented challenge. Television production, characterized by firmly established work routines, is having to adapt to make use of the possibilities offered by the different media and to break away from established criteria of time and space in the consumption of television, as described by Uricchio (1999), to create new forms of expression and interaction with the audience in a crossmedia manner.

In this setting, the analysis of cross-media content may seem new, but its perspective of study is nothing recent. Interest in this field is related with the attention that has been given to the new media and how these depend on or reproduce the characteristics of their precedents. Bolter and Grusin (1999) define the characteristics of the contents that are presented in various media using the concept of remediation, which is the representation of one medium in another. Although the authors do not explicitly speak of the cross-media phenomenon, this was a seminal study in terms of the theory of relationships between old and new media. The authors explain how the new media are reshaping preceding media conventions and vice versa, as part of an operation in which some change the others, creating new hybrids.

Ribas (2009: 47) interprets remediation in the digital context as an "appropriation of the old media by the new - polymorphic like never before in the digital case- provoking the appearance of this productive tension between the experience of the absence and presence of the media, between immediacy and hypermediacy. A unified space in which we penetrate a kind of window, hypermediacy opposes a heterogeneous space that visualises in different parts or channels, perhaps 'windows', the representations of the other media, which opens possible windows on the diverse sensorial varieties of the experience".

Thus we see how the idea of remediation is guided by two contradictory logics: immediacy and hypermedia. Immediacy explains how a visual style seeks to make the viewer forget about the presence of the medium and make it transparent, while the concept of hypermedia refers to the visual style whose aim is to remind the viewer of the presence of the medium by means of its own codes. For example, a programme's website not only reproduces what is shown on television, but also creates a new environment using hybrid content adapted to the medium (Bolter and Grusin, 1999). Fagerjord (2003) criticises the focus used by Bolter and Grusin (1999) because it does not emphasise communication, but rather the status of each medium within a certain culture and how this status is achieved, changed or defined. For Fagerjord, the key concepts of remediation theory, hypermedia and immediacy, are confusing because they differ from one text to another and from one reader to another and are hence insufficient for explaining the relations between different media 
because it is not always possible to distinguish the preceding medium that is concealed behind the succeeding medium.

Although the concept of remediation fits with the perspective for the analysis of new media, this is not a new phenomenon. In fact, from the outset, television was also a parasitic medium that developed genres that originally belonged to the theatre, radio and cinema (Gorman and McLean, 2009). However, in the last decade of the 20th century, with the appearance of new user terminals and broadcast networks, the notion of remediation acquired a relevant weight in an environment in which each medium sought to achieve a certain cultural status and to stand out from the others. Ribas (2009:48) interprets remediation by saying that "we shall explicitly emphasise what we believe to be the most significant characteristic of the interactive medium, an integral consideration of the relation between media and the management of the users' actions. Few authors have insisted enough on this. Even Bolter and Grusin seem to view hypermedia as nothing more than a simple collage of pervious media that have been 'remediated' by the digital monster." The media, from this theoretical focus, are more than a technology with a certain class of significant units (written language, moving images or photographs). They are the result of the combined effects of technology, economy and social practices. Fagerjord (2003) recurs to Williams (1975) to explain why technology is not the only determining factor of the evolution of the media and claims that many of the aspects and characteristics that are attributed to television are not inherent to the medium, but are rather the result of the interaction of a technology with society (Gorman and McLean, 2009).

Other authors warn of the implications of technology in the medium of television. "All screens can serve multiple ends, although each, depending on the characteristics of their size, luminescence, definition and position, will be more adequate for one function or use than another. In whatever case, this is the end of the epoch in which the reception device and the medium were synonymous" (Prado, 2009: 36).

\section{Contributions from semiology}

The notions of intertextuality, intermediality and transtextuality have been used to identify the relationships between texts, and have therefore proved especially useful in the study of content or discourse analysis from a semiotic perspective. Intertextuality has been used in content studies to systemise the operations of connecting and creating typologies, and in sociological analyses to examine the associated processes. This mode of comparison crosses concepts from different humanistic disciplines with social studies in order to understand how texts can acquire different meanings depending on their spatial or temporal context. Intertextuality was a concept introduced by Bakhtin (1981) that has been widely used since the study by Julia Kristeva (1984) in media studies (Jensen, 1999). This theory has been used to identify the rela- 
tions between products, media and communication processes. Of note among the investigations in these fields are two focuses, one that deals with the characteristics of discourse to reveal the connection between certain words and others (Bakhtin, 1981) and another of the social practices around this, i.e. the identification of the relations between text and context.

Instead of intertextuality, Jensen (1999) applies the concept of intermediality to study nexuses between words. The author considers that all the messages in a text are always one medium and that intermediality explains the borders and relations between the different media from a heuristic point of view. For Jensen (1999), the notion of intermediality responds to a combination of communication sustained on a technical, digital or human base that uses a group of expressive or representative forms to facilitate the social use of signs. Due to intermediality, words acquire meaning in relation with other words. Hence studies in the area involve the essential objective of finding out about the possible specific bonds between them. Jensen (1999) suggests an empirical method for such studies, in which the author's testimony should be combined with historical evidence that take into account the institutional context from which certain interpretations or meanings originate.

Genette (1989) opts to use the concept of transtextuality to study the relationships between texts in accordance with five degrees of relation: Intertextuality understood as a relation of explicit co-presence between two texts, for example, the textual citation of one author by another; paratextuality described as a relation between a text that is strongly associated to the original, for example, a trailer to promote a movie and the movie being shown; metatextuality conceived as a critical relation between two texts, for example, a cinematographic summary and the movie it is referring to; architextuality defined as a change of genre between two texts, for example, a comedy that becomes a tragedy following an adaptation process; and finally, hypertextuality delimited by a total transformation or modification of the original text, for example, a book adapted to the cinema.

In summary, transtextuality is defined by Genette (1989) as everything in a text that is related with another, whether or not this relation is obvious. As Jensen (1999) notes, this definition presents some problems because it does not differentiate between relations that were premeditated from those that arise out of coincidental associations between texts, or those that are immediately apparent from more profound ones. It is also difficult to apply the levels of transtextuality in all cases and its typology does not consider the social structure of texts or the use and consumption of the same, and as Lacalle (2010:34) warns: "the impact of television transcends the intentions of the programme designers, to the extent that it can condition viewers in quite unexpected ways, because the relation with the media is not cognitive but rather implies emotional responses, entertainment and cultural appreciation".

Some authors have adapted these and other theoretical concepts to their own studies of cross-media content. For example, Fiske (1987) proposes in his book Television Culture a distinction between vertical and horizontal inter- 
textuality. Horizontal explains the transfer and accumulation of meanings between different primary texts or words, such as the genres, characters or themes and vertical intertextuality identifies another type of relation that arises from so-called secondary texts, because they are not related in time with the primary text. This occurs, for example, with reviews, the audience's contributions to a certain content and texts that are formed as a conversation about another text. Unlike studies focused on hypertext, in which possible connections between various texts are studied on the basis of interaction, Fagerjord (2003) claims that the mere union of a video clip with a text originating from another medium causes the emergence of a new text with a new author. In this case, rhetoric convergence describes the conventions or categories of this mutual coexistence.

\section{Cross-media creations "Guernica, pintura de guerra" on TVC}

Crossmediality can be understood as a network of assembled and related units in a material and sensorial dimension. The union of creation, according to Bechmann Petersen (2009), seeks stabilisation by means of rules and structures that are complex and hard to identify. In this maze, each part has its own properties that are binding objects at the same time. Hence, cross-media content is the consequence of hybridisations between media, a process during which they lose part of their individual identity and acquire the characteristics of others. In summary, their distinctive property is their network character because they are created on the basis of linking points (Bechmann Petersen, 2009), where different communication platforms are related in terms of sound, pictures, text or data and the production is performed transversally because each platform operates beyond its own limits.

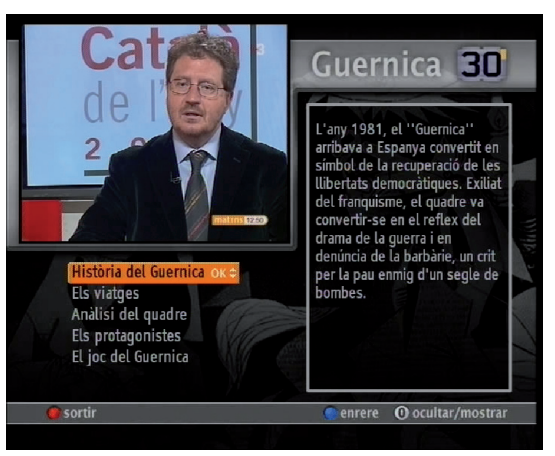

Figure 1. Image of the interactive application for TDT from the documentary Guernica Pintura de Guerra. Provided by Ccrtvi on $05 / 03 / 2009$

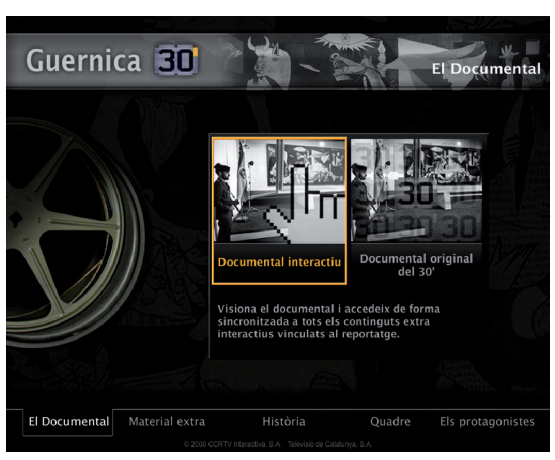

Figure 2. Image of the application for Home Media Center from the documentary Guernica Pintura de Guerra. Provided by Ccrtvi on 05/03/2009 
We can analyse this relation on the basis of the practical case of a crossmedia production by Televisió de Catalunya (TVC): "Guernica, pintura de guerra". This interactive documentary was designed as a production to depict the events of 70 years ago when German aircraft under Franco's command bombarded Guernica. Picasso's painting became a universal icon that sought to show the barbaric nature of the attack. The documentary shown on the "30 minuts" programme, broadcast on January 21, 2007, was designed as an interactive development for TDT set-top-box with the Media Home Platform (MHP), Media Center and an extensive website was created. We agree with Gifreu that the idea of this production "apart from being interesting from the multiformat and multiplatform point of view for which it was produced, also shows excellent richness in relation to the different modalities it presents and the way they are combined" (2009:132).

In this case, viewers could watch the documentary linearly on television without interruptions or interaction. But MHP or Media Center users could access in real time specific applications that complemented the linear content. This was limited content adapted to the characteristics of the technological device that did not permit the kind of extensive developments possible in the web environment.

The relations between cross-media content are in turn delimited by the culture, existing media and the social actors involved (Finnemann, 2006). In this case, a universal cultural reference is chosen, as is the work by Picasso, which facilitates the explanation and argumentation of a local historical event that transcends that territory and population. Similarly, the existing media became conditioners of what could be offered to audiences, which not only refers to the resources destined for production. We consider another factor derived from the lack of MHP or Media Center terminals among the Catalan audience, a situation that constitutes a veritable problem due to the low viewing figures that can be achieved by these two platforms.

In short, cross-media content is the result of the co-evolution of media in which each acquires parts of the other. But what parts of the message are transferred and how does this happen? In these symbiotic relations between platforms, the narration is modified, genres are adapted and temporal proposals are configured in accordance with the specific characteristics of the device. In the chosen example, the documentary "Guernica, pintura de Guerra," the limitations of the MHP platform itself and those derived from the developers' lack of previous experience created an information service and an interactive quiz game that is related with the content being shown and allows several people to play via the television set. The application can be consulted during the broadcast and on the following days. The service expires very quickly and it has little impact.

In the case of the application for Media Center, a greater amount of information is provided, including bonus interviews, documents and pictures. In this case, the screen is split in two, one half showing the documentary and the other showing the interactive application itself. This idea is conceived with 
innovation and experimentation in mind, although it would be unjustifiable if only considering the quantitative variable of the number of operative terminals among the television viewers in the region.

Those responsible for cross-media production explain the intention and limitations of the project using the following terms: "The idea was to have a single idea but to differentiate between products, for example we knew that we could not put additional video on TDT, but we could with Media Center. For Media Center and TDT, the remote control is used, but a mouse is used for the Internet. The idea was to put all those elements on the table, using the same basic idea or concept as the documentary, which has a narrative thread. Aesthetically we wanted it to look the same, and for the user's experience to be as similar as possible but at the same time for it to have a distinctive feel to demonstrate the abilities of each" (Interview with Ferran Clavell, 2009).

The producers should understand the possibilities and limitations of each platform to adapt the narrative structure and resources on offer to these characteristics. Moreover, the audience is increasingly more familiar with these transmedia creative proposals, which develop complementary content to that offered on television. This production process on digital platforms makes it possible to exploit and reuse the content while also creating a route between platforms and supports.

This transit is increasingly more natural and accepted. This learning has years of history behind it, which in the case of radio and television has accelerated over the last decade through the development of widespread and sustained web activity. Specifically, web projects look to benefit from these circuits and nodes of concomitance with the different contents available. The creators of the documentary, Santiago Torres and Ramon Vallès, explain that the television script consists of some 20 folios, but the interactive script produced by the Corporació de Ràdio i Televisió Interactiva (Ccrtvi) contains some 100 folios. The television documentary lasts one hour, but the additional services offer between five and six further hours of interviews. The producers of "30 minuts" often record 30 to 40 minute long interviews, of which only 20 to 30 seconds are actually shown on television, but thanks to the possibilities offered, the Internet and Media Center versions use some 20 minutes of each interview.

In the analysed case of the "30 minuts" documentary, a complete, extensive and ambitious website was implemented. In this case, the possibilities for combination are greater than on previous platforms as a result of the versatility of the tool. There are no time limitations or restrictions in terms of writing length. Therefore, the richness of the contents can be greater and relations with users more intense and purposeful. The idea is to achieve this through the implementation of a creative experience, which requires participation by the user. Once the action has been performed, it is saved and can be shared with all the other subjects that access the application and wish to visualise it.

The application called Shafrazi Experience consists of the emulation of young Tony Shafrazi who in 1970 spray-painted the Picasso painting on dis- 
play in New York in protest against the United States' intervention in the Vietnam War. The users of the application are encouraged to emulate what the young American did using painting tools provided as part of the application and then to display their creation. Another matter will be the acceptance of the proposal by the audience, which is not always as expected. The degrees of purposeful participation in this first production were no more than symbolic.

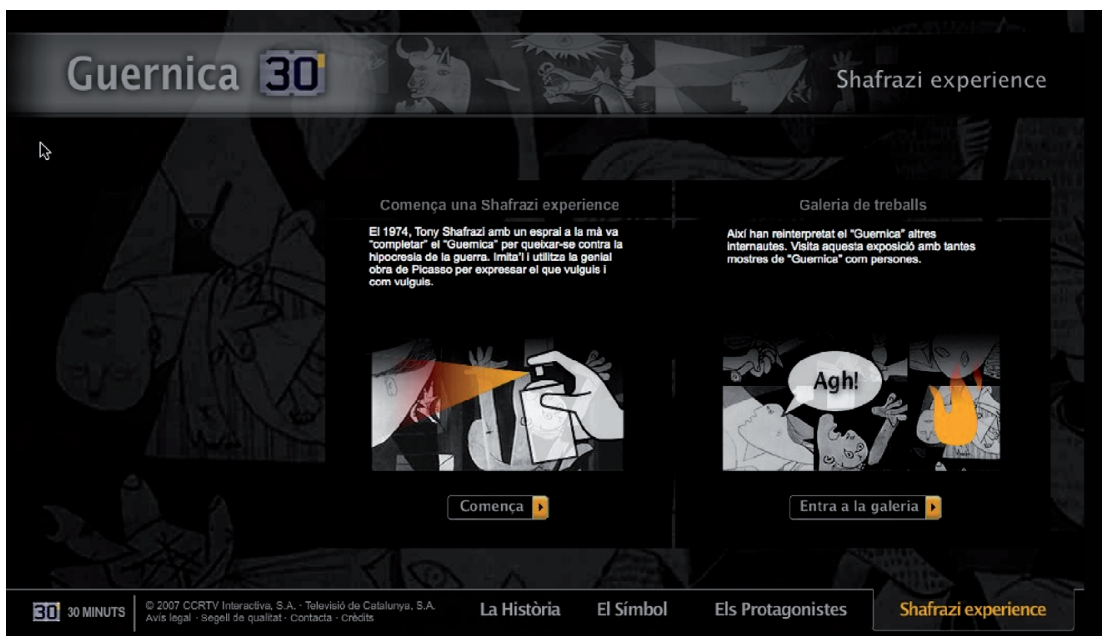

Figure 3. Image of the website of Shafrazi Experience. Provided by Ccrtvi on 05/03/2009

In this case, we could use the concept of reconfiguration (Manovich, 2008) to explain the visual, phonetic and conceptual relations in which some content makes reference to other previous content. The author states that the associated structures arise on the basis of the media understood as an outlet through which an item of content is available to the user on an interface and related by the message, grammar or use. Reconfiguration arises as a result of a synergy between languages and visual techniques. However, in the analysed proposal there is no veritable hybridisation that permits the editing or creative design of any type of content.

These more advanced reconfiguration proposals have not been implied in the case of the interactive documentary. The proposed tools for interaction only enable actions involving the choice of contents and interactive proposals based on games or the creation of a work of art using the emulation of Shafrazi's action, so we can only classify them as embryonic attempts at such reconfiguration.

Reconfiguration emerges as the result of a synergy between languages and visual techniques. A hybridisation in digital culture due to the use of software that permits the alteration of the editing and creative design of any type of content, such as commercials, music videos, television graphics, cinematogra- 
phic design, cell phone interfaces and any other type of support, for which common instruments are used that integrate the media and techniques to create hybrids despite the continuous changes of style in the design (Manovich, 2008). To define the concept of the hybrid medium, the author distinguishes between multimedia and reconfiguration during the construction of the message. The term multimedia was popularised in the 1990s to describe electronic applications and documents that have a nexus between them. These media include texts, graphics, photographs, videos, 3D scenes and sound, for example in a website. Reconfiguration alludes to a more advanced study. In this new environment, the contents exchange properties, create new structures and interact on a more profound level (Manovich, 2008). Multimedia contents appear next to the other, i.e. an image appears along with the contiguous text of the video; however, in hybrid media all of the content merges to produce the result of another.

In the case of media hybrids, interfaces, techniques, and ultimately the most fundamental assumptions of different media forms and traditions are brought together resulting in new species of media. To use a biological metaphor, we can say that media hybridity involves the coming together of the DNAs of different media to form new offspring and species (Manovich, 2008: 89).

In short, thanks to multimediality, reconfigurations, new forms of graphic representation, navigation and interaction structures, interfaces and tools, i.e., hybrid media, are produced. The tools and techniques for the creation of hybrids or remixes that affect the narration, style, composition or design have not been used in the documentary "Guernica Pintura de Guerra". However, we can find them in other multiplatform contents with a greater degree of interaction and implication of the user.

\section{Understanding the productive conditioners}

The media have been obliged to accept certain changes in their productive structures as a consequence of convergence. A qualitatively different media scenario featuring new actors that are anxious to compete in the audiovisual market and that also possess operative skills in virtual environments. Meeting the challenges derived from these evolutions and skilfully handling the adaptation to the technological transformations to which communication organisations are subjected has become a crucial element. This technological change has a direct influence on the media's strategies and their capacity to respond in this area determines their future (Küng-Shankleman, 2008). Internet is a perfect example of how the introduction of information and communication technologies has the potential to destabilise traditional business models (Mierzejewska, 2010).

When analysing multiplatform content, it is crucial to understand the audience's requirements, as they demand greater levels of personalization 
and/or implication in the messages than in previous times, and the conceptual and narrative proposals of cross-media content form part of this dynamic. "Rather than talking about media producers and consumers as occupying separate roles, we might see them as participants who interact with each other according to a new set of rules that none of us fully understand" (Jenkins, 2008: 15).

When expanding their activity to multiple platforms or devices, radio and television corporations have required the collaboration of specialised professionals and companies who are able to take on some of the production in aspects related with the services associated to interactivity. This tendency has existed since the beginning of web-based activities. In the different phases of the evolution of television channels "there is a high amount of division of work that combines the efforts of producers, technicians, reporters and professionals in different areas of the company. In addition to this productive ecosystem, there are external companies that produce or coproduce for the medium and that are increasing in number as a result of the pressures of a globalised market" (Franquet and Villa, 2010: 392).

The creation of the interactive services for the aforementioned documentary involved the participation of the Haiku Mèdia company and more than a dozen Ccrtvi professionals associated to the area of content, design and development groups and the exploitation of the technical area of this subsidiary of the CCMA. While the development professionals worked on the technical requirements of the project during its implementation stage, the exploitation team guaranteed the proper operation of the services. In the production process, which took almost a year, there was also a professional involved who acted as a link between TV3 and Ccrtvi. The production also required periodical meetings between the directors of the documentary and the parties responsible for the design of the interactive contents, at which contents were agreed for each platform in accordance with the editorial criteria established by the production team and the available material.

One of the most laborious tasks in this process is the consultation and administration of the archive material because the documentary includes a large number of unpublished images taken from more than 50 archives around the world. The creators had to overcome technical and rights management difficulties. A strategic variable involved in any type of multiplatform production.

In addition to the inherent difficulties with documentation there were problems with rights management. We had to explain to the owners of the archives that as well as broadcasting on television, we would also make an interactive part that would be on the Internet, in Media Center and TDT, but a lot of them didn't know what we were talking about. Each platform has its rights. On Internet, the material would be available for a year, while for television we only needed rights for two or three showings on Canal 33, TV3 and the international satellite channel. The interactive application for TDT would be available for a week and the Media Center one for a year. It was much more complicated 
with that platform, a lot of archivists did not know this system and there were no regulations to cover it. They asked us 'media what?"' (Interview with Santiago Torres and Ramon Vallès, 2007).

Digital contents evade linear narrative as happens with computer games in which there are narrative styles involving several options within the construction of scripts. Jeffery-Poulter (2002) encourages producers to move away from linear narration and to use different types of script with different structures in which the user can easily move from one phase of the story to another. This peculiarity is achieved in a web proposal for the product we analysed, done in the form of a diagram of the structure and narration divided into three sections: the protagonists (the characters), the history (the chronology) and the symbol (the painting). An easily identified structure and that in the case of chronology has been extensively used since the first interactive products produced for offline or online analogue or digital supports.

Another of the outstanding theoretical proposals to typify the characteristics of contents in a cross-media environment is that by Erdal (2007), which is related to the rhetoric convergence model suggested by Fagerjord (2003) to study the variations and interrelations of content between several platforms and to identify three different ways of achieving content in a cross-media environment from the productive point of view: rhetoric of augmentation, rhetoric of recombination and rhetoric of reversioning. Although the author uses an example dedicated to the current affairs environment, his reasoning can also be used for our purposes.

The rhetoric of augmentation uses the same image, sound or audio material in more than one medium. The phenomenon is based on the cannibalization of contents in the production process, and which is determined by copy and paste actions. So, for example, the same video of the interview shown on television is used in the website of the documentary "Guernica Pintura de Guerra" or part of the historical information that appears on the website is transcribed for the Media Center and the TDT MHP terminal.

In the second stage of adaptation, rhetoric of recombination, the production introduces different content from different media and uses the documentation from the core text, in this case the documentary produced for television, to make a different version for the website. Similarly, a new version emerges, rhetoric of reversioning, from the recombination of productions characterized by the use of different types of software and hardware to construct a heterogeneous product. Erdal (2007) exemplifies this type of content as a news story that first appears on the web, is illustrated in a television image and depends on a story that was also published as an analytical article in the press. In recombination, each medium makes its version of the story and uses the material made for other platforms to do so. As this is not information that evolves with the current state of affairs, only a part of the contents are made without evolution, while another portion is adapted to create a new version. 
In news environments, these actions can depend on a multi-task professional being responsible for producing for all platforms, or on multidisciplinary teams. In the former case, when just one reporter produces the content, these are generally characterised by being almost identical. For example, a professional initially covers a news story for television, but then uses the same soundtrack for the radio or web, and uses the television video to obtain the frames used to illustrate the story on the Internet.

However, when the work depends on a multidisciplinary team, as is the case with the analysed documentary, the content can be totally differentiated between platforms even though it refers to the same subject. The participation of professionals from different media facilitates the enrichment of the content, benefits convergence and represents a significant advance towards cross-media cooperation.

5. Experiences of the consumption of multiplatform contexts

At present, there is increasing pressure to attract the audience's attention and maintain its level of interest in flowing narrative proposals. At the same time, now that the tendency towards personalised viewing has been accepted, intense strategies are being developed to exploit this form of disaggregated consumption of broadcast time. In the first phase, the proposal is being linked to services like YouTube, where specific channels are created to control the content being supplied. In a second phase, catch-up services are being developed, which will soon be consolidated as an efficient platform for radio and television broadcasters whose YouTube activities are flagging. In these services, the content can be provided in different combinations and fragments to those originally shown on television. However, the platform's purpose is to maintain the original audiovisual product and identify the content with the television space and its scheduling in a symbiotic relation between the broadcast flow and on demand services. At the same time, multiplatform diversification strategies in the case of mobile telephones observes, in very general terms, the same logic. However, the peculiarities of the devices enable other specific proposals that require different levels of participative activity.

Such forms of consumption can be identical to those broadcast conventionally using catch-up interfaces or through complementary proposals produced in different levels of depth in order to create intense empathic processes that guarantee an ongoing relation that is faithful to the television image. But these strategies had not yet been developed in 2007, when the analysed documentary was presented. At that time, the creation of a DVD seemed to be the best way to extend and prolong the useful life of an audiovisual product.

Jeffery-Poulter (2002) indicates that it is advisable for the audience's contributions and tastes to be actively included during the editorial creation process, rather than afterwards. But to do this, as stated by Huertas (2002), there is an imperious need to reappraise the principles that govern the measuring of audiences and its methodologies because, among other problems, the size of samples and the number of variables used are very small in comparison with the extension of the universe being studied and its level of fragmentation. 
A week after the television broadcast of "Guernica Pintura de Guerra", the producers already had viewing figures for that platform. The documentary had been seen by some 600,000 viewers. However, there was no knowledge of the data for the multiplatform consumption for two reasons, first because this is the job of different companies and secondly because each platform used different measuring systems and time periods, which meant that the simultaneousness of the data was not viable.

Audiences voluntarily access and are exposed to the multimedia proposals generated by television operators for different screens. This exploratory process can involve complementary motivations to consume related with the television broadcast, but which transcend the same, as the exploration of contents is done using external sources to the television flow.

The audience experiences interest and motivation induced by a certain television programme (Moorman et al., 2007) that is consumed in a transmedia context where the transit between units of content is a simple affair. The capacity of digital platforms to reproduce or simulate the content of others and thus create dependence constitutes its main strength. Modern day multiplatform projects tend to exploit the technological advantages and the expansion of texts to their multiple recombinations. New texts that are complemented with communicative experiences associated to the common practices of the users of social networks.

\section{Bibliography}

Bakhtin, M. M. (1981). The Dialogic Imagination: Four Essays. (C. Emerson; M. Holquist, Trad.) Austin: University of Texas Press.

Bechmann Petersen, A. (2009). Crossmedia: Innovation Networks for Traditional Media Organizations. Tesis Doctoral. University of Aarhus.

Bolter, J.D. \& Grusin, R. (1999). Remediation: Understanding New Media. Cambridge: MIT Press.

ERDAL, I. J. (2007). "Researching media convergence and crossmedia news production". Nordicom Review. Vol. 28, núm. 2, pág. 51-61.

FAgERJord, A. (2003). Rhetorical Convergence. Earlier Media Influence on web media form. Tesis doctoral. University of Oslo.

Finnemann, N. O. (2006). "Public space and the coevolution of digital and digitized media". Tidsskeriftet Politik. Vol. 9, núm. 2, pág. 64-73.

FIsKe, J. (1987). Television Culture. London: Methuen.

FRANQUET, R. y VILLA, M. I. (2010). "Gestores de contenido en la arquitectura de la producción multiplataforma. El caso de Televisió de Catalunya". El profesional de la Información. Vol. 19, núm. 4, pág. 389-395.

Genette, G. (1989). Palimpsestos: la literatura en segundo grado. (C. F. Prieto, Trad.) Madrid: Taurus.

Gifreu, A. El documental multimèdia interactiu. Una proposta de model anàlisi. Treball de recerca. Departament de Comunicació. Universitat Pompeu Fabra, 2009-2010. 
Gorman, L. \& McLean, D. (2009). Media and society into the 21st century: a historical introduction. Malden, MA: Wiley-Blackwell.

Huertas Bailén, A. (2002). La Audiencia investigada. Barcelona: Gedisa.

JefFery-Poulter, S. (2002). "Creating and producing digital content across multiple platforms". Journal of Media Practice. Vol. 3, núm.3, pág. 155-164.

Jenkins, H. (2008). Convergence culture: La cultura de la convergencia de los medios de comunicación. (P. Hermida, Trad.) Barcelona: Paidós.

Jensen, K. B. (1999). "Intertextualities and intermedialities". En: I. Bondebjerg y H. k. Haastrup (eds.). Intertextuality and Visual Media. Copenhagen: Departament for Film y Media Studies, University of Copenhagen, pág. 63-85.

Kristeva, J. (1984). Revolution in Poetic Language. (M. Waller, Trad.) New York: Columbia University Press.

Küng-SHAnKLEMAn, L. (2008). Strategic management in the media: From theory to practice. Los Angeles: Sage.

Lacalle, C. (2010). Joves i ficció televisiva: representacions i efectes. Anàlisi. Núm. 40, pág. 29-45.

Manovich, L. (2008). Software takes command (Borrador del Libro) [en línea]. Software Studies Initiative. [Fecha de consulta:10/12/2010] <http://lab.softwarestudies.com/2008/11/softbook.html>

MierzejewskA, B. (2010). "Media management in theory and practice". En: M. Deuze (ed.). Managing media work Reino Unido: Sage, pág. 13-30.

Moorman, M.; Neijens, P. C.; Smit, E. G. (2007). "The effects of program involvement on commercial exposure and recall in a naturalistic setting". Journal of Advertising. Vol. 36, núm. 1, pág.121-137.

PrAdo, E. (2009). "Reptes de la convergència digital per la televisió. Convergència tecnològica i audiovisual". Quaderns del CAC. Núm. 31/32, pág. 31-42.

RiBAs, J.I, (2009). "Integració de mitjans en el discurs interactiu: el cas de la difusió cultural”. Quaderns del CAC. Núm. 31/32, pág. 44-53.

Williams, R. (1975). Television: Technology and Cultural Form. New York: Schocken Books.

URICCHIO, W. (1999). “Intemedial challenges to television's definition”. En: I. Bondebjerj y H. k. Haastrup (eds.). Intertextuality and Visual Media. Copenhagen: Departament for film y Media Studies University of Copenhagen, pág. 171-183.

Rosa Franquet. Catedrática de Comunicación Audiovisual y Publicidad de la Universidad Autónoma de Barcelona. Directora de Proyectos del GRISS (Grupo de Investigación en Imagen, Sonido y Síntesis). Coordinadora Académica de los Estudios de Doctorado "Contenidos de Comunicación en la era Digital” y del Máster oficial "Investigación en contenidos en la era digital'. Presidenta de la Societat Catalana de Comunicació, de l'Institut d'Estudis 
Catalans y directora de la sección "Comunicación y Cultura Digital" de la Asociación Española de Investigadores de la Comunicación (AE-IC). Editora de la revista Comunicació de la SCC. Miembro de comité científico y editorial de la revista Telos. Ha sido investigadora y profesora invitada en diversas universidades nacionales e internacionales como la University of Melbourne (Australia), University of California at Berkeley, University of California, at Davis, University of London (Goldsmiths), Universidade de São Paulo, Iberiomericana de México o Adolfo Ibáñez de Chile. Forma parte del equipo evaluador del Seventh Research Framework Programme de la Unión Europea y anteriormente del Sixth Research Framework Programme. En 2004, recibe el premio de investigación del Consell de l'Audiovisual de Catalunya. Es especialista en Comunicación interactiva, radio y televisión y ha publicado numerosos artículos y libros.

María Isabel Villa Montoya. Doctora en Contenidos de Comunicación en la Era Digital con mención europea. Actualmente se desempeña como profesora en la Facultad de Comunicación Social de la Universidad Pontificia Bolivariana. Ha trabajado en la Universitat Autònoma de Barcelona como docente investigadora en formación y es parte activa del Grup de Recerca en Imatge, So i Síntesi (GRISS). Ha sido estudiante doctoral invitada a participar en las actividades de investigación del grupo Business and Information Technologies (Roskilde Universitet), en el Centre for Internet Research (University of Aarhus) y en el grupo de investigación Marketing Research (Univertiy of Antwerp). Sus intereses académicos incluyen el cambio de los operadores públicos de radio y televisión, los medios digitales, las tecnologías de la comunicación, la televisión y la fotografía periodística. Sus publicaciones se ocupan principalmente de la producción de la televisión en el entorno cross-media, la participación de la audiencia en las webs informativas y la fotografía en los medios informativos online. 